\title{
IKT ESZKÖZÖK A TANÍTÓKÉPZÉSBEN
}

\section{SZŐKE ENDRE}

\author{
a Börzsöny Általános Iskola \\ tanítója \\ szoke.endre70@gmail.com
}

\begin{abstract}
A tanitó tevékenységét, az általa alkalmazott módszereket, azok hatékonyságát, sikerességét mindenkor több tényezö befolyásolta. Ezek közé tartoznak a taneszközök, oktatástechnikai eszközök, napjainkban pedig az IKT eszközrendszere. Az információs társadalom „,digitális gyermekéhez” s az ehhez társuló viselkedési attitüdök - a felnövekvö nemzedékek esetében robbanásszerü - megváltozásához alkalmazkodnia kell az iskolarendszernek, hogy feladatát a továbbiakban is sikerrel el tudja látni. Erre az egyetlen hatékonynak tünö mód, a digitalizált világ, az IKT eszközök oktatási folyamatokba való integrálása. A tanulmány célja a kultúránkat behálózó, cselekedeteinket napi szinten is befolyásoló tényezö, az IKT néhány jellemzöjének bemutatása, az iskola kezdö szakaszában való alkalmazási lehetőségeinek ismertetése.
\end{abstract}

\section{Infó-kommunikációs technológia}

A múlt század 50-es éveiben - a világháború technológia és szellemi kapacitás elszippantó hatását követően - a müszaki tudományok nagymértékü fejlődése idején hangzott el először az „információ kora” kifejezés, ahogyan ekkorra tehető a „tudásalapú társadalom" elnevezés megszületése is. Közben eltelt egy emberöltő, s most már a számítógép szinte minden fejlesztés forrása. Ahogy a kezdeti teljesítményt elképesztő módon túllépve fejlődött a számítástechnika, újabb és újabb eszközökkel bővült a kommunikáció, kialakult egy új, mára már hétköznapivá vált kifejezés az „információs és kommunikációs technológia” - IKT (Békési, 2010).

A fogalom megjelenése a 90-es évekre tehető (Lengyelné Molnár, 2013). Ekkor használták először az „információs müveltség” kifejezést is az angolszász országokban (Koltay, 2010). Szélesebb körben a 2000-es évek elején terjedt el. Ennek egyik oka, hogy az EU különböző fórumai szorgalmazták az IKT hangsúlyozását az oktatás területén, amelyek segítségével biztosítottnak látták az információs és kommunikációs müveletek hatékony alkalmazását az új évezred digitalizált világában is. Nagyobb jelentőséget adott az IKT-nak a 2006-ban megjelent EU-s állásfoglalás, amelyben a fejlesztendő 8 alapterület egyike éppen a „digitális kompetencia" (Körösné, 2007; Csik, 2011). 
Ez egyfajta válasz a napjaink egyre virtualizálódó világában megfigyelhető újfajta megosztottság kialakulására (Csepeli, 2003), amit Marc Prensky igen találóan fogalmazott meg. Szerinte az újabb nemzedékek, akik beleszületettek a digitális technológiák használatába, gondolkodásukban és információkezelésüket tekintve is alapjaiban térnek el a megelöző nemzedékektől (Jakab, 2011). Magam részéről a megosztás ilyen irányú megközelítését nem teljesen osztom. Tapasztalataim szerint jobban tükrözi a helyzetet, ha az eltérés természetét nemzedékek közötti különbség helyett egyéni okokra vezetjük vissza. Annál is inkább, mivel az információs korszak digitális generációját a hálózatiság, az ebből származó „korlátolt mindentudás" jellemzi. Ez pedig nem elegendő ahhoz, hogy modern világunkban eligazodni képes, sikeres, boldog felnőttkort biztosítson. Ez az alapja, az egész életen át tartó tanulás koncepciójának (Harangi, 2011).

\section{Technológia az oktatásban}

A történelem során, az oktatás fejlődésével párhuzamosan alakultak ki, újultak meg az ismeretátadási folyamatban alkalmazott oktatástechnikai eszközök, anyagok, amelyek a tudás befogadásának elösegítésében, az oktatás hatékonyságának növelésében játszottak szerepet. Fogalomkörébe az oktatási módszerek mellett a taneszközök (tankönyvek, szemléltető- és íróeszközök, írótáblák) is beletartoztak.

A 19. század végén felgyorsuló tudományos-technikai fejlődés, az iparosítás eröteljesen hatott az oktatásra - elsősorban közép- és felsőoktatásra -, annak módszereire, az alkalmazott eszközökre is. A megnövekedett tudásanyag, specializálódó iskolákat igényelt, megjelentek az első ipariskolák, megkezdődött a középfokú szakoktatás expanziója.

Azonban a gyermek - az aktuális történeti kortól, társadalmi formától, iskolai követelménytől, technikai fejlödéstől függetlenül - gyermekként gondolkodik, sőt úgy is cselekszik. Ezért a hatékony tanítás-tanulási folyamatok elvárásaihoz illö, a tanulót motiváló, életkori sajátosságaiból adódó kíváncsiságának, érdeklődésének megfelelő új szemléltetési formákra volt szükség, a növekvő információmennyiség sikeres integrálásának érdekében (Körösné, 2007). Forradalmi változás volt az addig statikus, taktilis, vizuális eszközök (fali tablók, földgömbök, tankönyvek) után olyan auditív, komplex taneszközök (episzkóp, fonográf, diavetítő, filmvetítő, hangosító berendezések) használata, amelyeket az elektromosság széleskörü alkalmazása tett lehetővé (Kikindai, 1990).

Mire a 20. század kezdeti évei elmúlnak, az oktatástechnikai eszközök, mint információs és oktatási segédeszközök nélkülözhetetlenné váltak az oktatás minden szintjén. Az általánossá váló oktatás mind szélesebb néprétegeket mozgatott meg. Egyre növekedett azoknak a köre, akik - köszönhetően az új módszereknek, a változó pedagógus szemléletnek és a technológia fejlődésének - számára kinyílt a világ. 
A következő oktatástechnikai fordulópont a 20. század ötvenes éveire tehető. Bár még a maihoz képest kezdetleges formában, erősen korlátozott képességekkel, de elindult - elsősorban katonai és kutatási céllal - diadalútjára a számítógép. Ez egyelöre nem vonatkozott az oktatásra, kivéve - elsősorban az USA-ban egyes egyetemeket.

Az oktatásban érdemes a számítógépek megjelenése előtti és megjelenésük óta eltelt időszak között különbséget tenni. Az 1980-as évek közepéig tartó időszak, a hazai oktatást tekintve túlnyomó részt a számítógép előtti korszakhoz tartozik. Kutatóintézetekben, a felsőoktatásban itt-ott már ismerték, használták a mai személyi számítógépek elődjeit. Nagyságrendileg azonban, éppen ebben az időben vált általánossá, szinte minden oktatási intézményben a különböző - rádió és televízió alapú elektronikus oktatástechnikai eszköz. Színesebbé, mozgalmasabbá vált a szemléltetés. Fénykora volt ez a diavetítőnek, az iskolarádiónak, iskolatévének, a különbözö magnetofonoknak, lemezjátszónak, írásvetítőnek, később pedig megjelentek a videó lejátszók, majd a felvevők is.

A magyar oktatásban a számítástechnika az 1980-as évek második felében terjedt el (Körösné, 2009), kezdetben a felsőoktatásban. Ezt tekinthetjük közoktatásunkban az IKT alkalmazás nyitányának. Már ekkor úgy gondolta a szakemberek többsége, hogy ez a technika alapjaiban változtatja meg életünket. Sajnos az iskoláztatás története során az oktatásirányítás, a pedagógusok - vallási, ideológiai, vagy egyéb okokból - gyakran ambivalens érzésekkel viseltettek az új módszerekkel, eszközökkel, gondolatokkal szemben. Ez az attitüd aztán nem egy esetben átbillent túlzott alkalmazásba (Kikindai, 1990). Nem történt ez másképp ebben az esetben sem. Sokan úgy gondolták, hogy az oktatás-nevelés marad a régiben, legfeljebb az informatika bizonyos elemei épülnek be az iskolai folyamatokba (Békési, 2010).

Talán elszomorító ez - a korokon átívelő - tendencia, hiszen a tanító, a tanár az, aki a tudást, a gondolkodni akarást, az új ismeretekre való törekvést el kellene, hogy hintse a következő nemzedékeknek, a velük való foglalkozás során. Más oldalról vizsgálva a témát azonban nem hagyhatjuk figyelmen kívül azt a tényt sem, miszerint az egymást követő generációk szinte minden tagja kapcsolatba került és kerül valamilyen szinten az oktatással. Ez pedig nem zárja ki annak a lehetőségét, hogy bár kezdetben általános lehet a visszafogottság a pedagógusok részéről, a későbbiek során ez a viszony fokozatosan pozitív irányba változik. Saját tapasztalatom szerint valóban ez történik. Egyéni tempóban, különböző módon, de a tanítók, tanárok, oktatók túlnyomó többsége adaptálja az újat. Legyen az technikai, vagy éppen elméleti újdonság. Épp csak felelős - netán tudós - szakemberként megfontoltan teszi azt, nem pedig vakon, körültekintés nélkül.

Noha az elmúlt évtizedekben, az informatikát tekintve több, nagymértékü, központi fejlesztés indult (1984 elektronizációs kormányprogram, 1998 Sulinet), a tartalomfejlesztés, az innováció, illetve az érintett oktatók felkészítésének hiánya miatt a fejlesztés lassú, a hatékonysága hullámzó. Szemléletes példa erre az 1984-es 
program, amelynek során minden középiskola 1 darab mikroszámítógépet kapott. Összességében 1988-ig az oktatásba mintegy 34 ezer, ebből az alapfokú oktatásba közel 19 ezer számítógép került (Szakadát, 1992). Ám ebből mindössze 1\% Pc, és 7\% Commodore64, a többi még ennél is alacsonyabb szintü ,játék” gép, melyekhez a pedagógusok részére - az informatika tanárin kívül - egyéb képzés nem társult. Ennél sokatmondóbb adat az általános iskolákban az egy számítógépre jutó tanulók száma, amely 72 fö.

Ezen a helyzeten az sem változtatott lényegesen, hogy a pedagógusok kezdeti ellenállása, elutasítása - köszönhetően az otthonokban elterjedőben levő számítógépeknek is - már a 90-es évektől kezd megváltozni (Békési, 2010). Ez a folyamat pedig fokozatosan legyürüzik az oktatás kezdő szintjére, az általános iskolák alsóés felső tagozatába is. Mire 1998-ban elindul a Sulinet, már nagyobb a fogadókészség az eszközállomány fejlesztésére, a számítógépek hálózatba kapcsolására, illetve ezek iskolai alkalmazására.

Az ezredforduló óta, az addiginál is szélesebb körben terjedt el a számítástechnika, mindennapi eszközökké váltak a számítógépek. Megszoktuk, hogy életünk bármely területén találkozhatunk velük, így az oktatási intézményekben is. Eközben folyamatosan bővült az informatikai eszközök tára is. Ahogy a fejlödés során fokozatosan elmosódni látszik az informatikai-, távközlési-, kommunikációs eszközök és elektronikus médiumok közötti határ; megjelennek az IKT eszközök, és kezünkbe kerülnek ennek újabbnál újabb változatai. Az internet, az okos telefon, a projektor, az interaktív tábla, a hipertext, a multimédia, a Web 2.0 világában elképzelhetetlen, hogy az informatika tantárgy oktatásán túl, egyéb módon ne alakítsunk ki kapcsolatot az elektronikus médiumok, az IKT eszközök és az iskola között.

McLuhan már az 1960-as években azt vallotta, hogy az iskola jelenlegi formájában nem képes megfelelni feladatának, hatástalan. Provokatív hangneme, a televízió elterjedésével kialakuló negatív folyamatoknak szólt, amelyek miatt megindult a kultúra gyökeres átalakulása, eltünik a „Gutenberg galaxis” (Komenczi, 2009), helyébe új, elektronikus kultúra lép. A tévéadásokon szocializálódó, szabadidejét a képernyő előtt töltő generáció tagjai nehezen igazodnak a hagyományos nevelési elképzelésekhez (Kósa, 2007). Történik mindez az új média több érzékszervet stimuláló, mozgalmas, később már színes adásainak hatására. A néző számára az otthonba, a mindennapokba hozza el a mozit, sajátos módon, akár folyamatos élményként. Talán túlzás profetikusnak jellemezni McLuhan sorait, de ma éppúgy igazak gondolatai, mint egykor.

„A nevelésnek segíteni kellene a forradalmi új környezet megértésében és a hozzá való alkalmazkodásban, ehelyett a kulturális agresszió eszköze, amely megpróbálja a retribalizált fiatalokra erőltetni egy halódó írásos korszak fölöslegessé vált vizuális értékrendszerét. Oktatási rendszerünk totális visszapillantó tükör (...), a múlt értékeihez és technológiáihoz igazodik. A generációs szakadék valójában elválasztó ür, amely nem két korcsoportot, hanem két teljesen divergens kultúrát választ el egy- 
mástól. A fiatalok nem fogadják el azt a steril oktatási rendszert, ahol a nevelés könyvvel kezdődik és végződik. Az oktatási rendszer teljes átprogramozására van szükség - a kihívások megértésére és kezelésére.” (McLuhan, 1969, 12-13. o.)

$\mathrm{Az}$ iskola, a pedagógus feladata nem változott, mindössze aktualizálódik az adott korra, környezetre. A pedagógus ma is a gyermek életkori sajátosságait figyelembe véve, érdeklődését felkeltve, motiválva őt, igyekszik hatékonyan véghezvinni a tudásátadást, továbbá olyan kompetenciákat, készségeket, képességeket kialakítani, amelyek segítségével képes az információs müveleteket (keresés, szelektálás, feldolgozás, tárolás, továbbítás) végrehajtani; az élethosszig tartó tanulás elvét szem elött tartva sikerrel boldogulni a tudásalapú társadalomban.(Harangi, 2011).

Ennek megvalósításához napjainkban elengedhetetlen az IKT alapismeretek megszerzése. A mai gyermekek nemzedéke már a mindent behálózó, mindenhol ott található digitalizáció virtuális világába születik bele. Nagyságrendileg más az ő gondolkodásuk, figyelmük, a könyvekhez, elektronikai eszközökhöz, a világhoz való viszonyuk, mint az elöttük felnövőknek (Hunya, 2011).

Az iskola sikerességének kulcsa a külső tudás, a tanulók digitális, informatikai ismereteinek felhasználása, integrálása az oktatásba, figyelembe véve az említett sajátosságaikat. Elsődleges a módszerek, az eszközök kiválasztása és alkalmazása, amelyek biztosíthatják a megfelelő kompetenciák kialakulását. Ehhez elégtelen a felső tagozatban megvalósuló heti 1 informatika óra, legyen mellette bármilyen oktatástechnikai eszköz. Főképp úgy nehéz használni az IKT eszközöket, ha csak a természetes tanulási folyamataikkal szöges ellentétben álló iskolai módszereket (Bessenyei, 2009) alkalmazva ismerkednek velük. Ezen a ponton kapcsolódik a témához az alsó tagozatos IKT nevelés, amely nem direkt informatika órákon történik, hanem más tantárgyak keretében, interaktív táblával támogatott formában. Már első osztályban közvetlen tapasztalatokat szerezhetnek a gyermekek az IKT eszközökkel kapcsolatban. A korábban említett - életkori sajátosságaikból is adódó - kíváncsiság, érdeklődés az új dolgok iránt nagyban megkönnyíti ezen eszközök beépítését a mindennapi tevékenységek sorába.

A számítógép, az internet és az ezekhez kapcsolódó egyéb infó-kommunikációs eszközök elterjedtek az otthonokban is. A 2-3 éves gyermekektöl kezdve nincs olyan korosztály, amely számára fokozatosan - eltérö módon és tempóban - ne épülne be használatuk készség szinten, tevékenységeik sorába. A 21. századi, mediatizált térben $(C s i k$, 2011) élő társadalom - elsősorban az ebbe beleszülető, fiatalabb nemzedék - jól alkalmazkodik az egyre jobban digitalizálódó környezethez. Sikeresen adaptálja az egyre fejlettebb technikai eszközöket, ezáltal sikerrel navigál (Csepeli, 2003) a médiumok által hordozott óriási információmennyiségben.

Szembesülnünk kell a realitással, a világ gyorsabban változik, mint ahogyan azt az iskolák követni tudnák. A médiumok, a számítógépek és az IKT eszközök, a virtuális média mindennapos - gyakran negatív - hatása, az esélyegyenlőtlenség új elvárásokat jelentettek, jelentenek az oktatás számára. Ahogy a társadalom szá- 
mára is erősödő probléma a digitális nemzedékek közötti különbség és a gyorsan fejlődő technológia - esetenként nyomasztó - hatása, úgy az oktatás számára is nagy kihívás ennek megfelelni, negatív következményeit kompenzálni. Az iskolák abban az esetben képesek hatékonyan megfelelni az információs müveletek technikáinak elsajátítását, és az élethosszig tartó tanulásra való felkészítést is magába foglaló társadalmi igénynek, amennyiben a szükséges kompetenciák, képességek kialakítása megtörténik. Ha a következő fejlesztési hullám komplex módon közelíti meg a témát, azzal biztosítaná a technikai fejlesztés mellett a módszertani és tudásbeli hátteret. Mindezeken túl a megfelelő motivációs stratégia erősítené azt a hatást, amely a - szabadidejükben már különböző szinten, IKT használóként tevékenykedő - pedagógusokat érinti.

A nyilvánvaló, talán egyetlen megoldás az oktatás modernizációjához az IKT erőteljes integrálása a tanítási-tanulási folyamatokba. Megkerülhetetlen az iskolák multimédiás és IKT eszközeinek gyarapítása, az oktatási tartalmak digitalizálása, a pedagógusok gyakorlatorientált továbbképzése; motiválásuk a módszertani váltásra, innovációra és infó-kommunikációs eszközök használatára való nyitottságra (Hunya, 2011). „IKT-eszközökkel jobban ellátott iskolák teljesítménye magasabb, mint kevésbé felszerelt társaiké."1

Kiváló megoldás lehet a probléma kezelésére az általános iskola bevezető szakaszában - már első osztályban, iskolába kerüléskor - is jó eredménnyel használható interaktív tábla. Pályázatok útján nagy számban jutott ebből az eszközből az ország általános iskoláiba, így azok alsó tagozatára is. Saját tapasztalatom alapján kijelenthetem, hogy azok a vállalkozó kedvü, nyitott szellemü tanítók, akik el is kezdték a laptop-aktív tábla-projektor alkotta egység tanórai és azon kívüli alkalmazását, jelentős változásról számoltak be. Megváltozott tanítási módszerük. Minél szélesebb körben alkalmazták - egyre jobban megismerve - ezeket az eszközöket, annál inkább fokozódott a gyermekek érdeklődése, aktivitása a használat idején. Nyilvánvaló, hogy függetlenül az iskola földrajzi helyétől, a gyermeklétszámtól, a tanulók könnyedén elsajátítják a különböző eszközök használatát. Amint aktív részeseivé válhatnak a tanóra menetének, érdeklődésük megnő, jóval hatékonyabb a képességfejlesztés, amelynek hatása föképp a valamilyen tanulási akadályozottsággal, nehézséggel küzdő diák esetében érezhető. A látás-, illetve hallássérült, „diszes” (diszlexia, diszgráfia, diszkalkulia) és egyéb tanulási zavarral küzdő gyermekek esetében a sikerélmény mellett (Bessenyei, 2009), a gyorsan, mérhető módon is megnyilvánuló fejlődés alapja. A számítógépes eszközök azonnali visz-

\footnotetext{
${ }^{1}$ Idézet az European Schoolnet 2006-os jelentéséből, Lengyelné Molnár Tünde által a 2013. november 12-én, Budapesten, a Médiatudatosság az oktatásban néven tartott OFI konferenciám, a „Az információs és kommunikációs technológiák, mint tanulástámogató rendszer" címmel elmondott elöadásán. (ppt. 8. o.) URL: http://www.ofi.hu/hirek-aktualitasok/lengyelne-dr-molnar Letöltés ideje: 2015. április 3.
} 
szacsatolást lehetővé tévő tulajdonsága, az észlelés komplex jellege segíti a feldolgozási folyamatot, a megértést (Földes és Körösné, 2006).

Az IKT eszközök alkalmazása ma már egybeforrt a kompetencia alapú oktatással, a kooperatív technikákkal. Ez utóbbi oktatásban való alkalmazása nem függ össze a technológiai fejlődéssel, sőt az IKT térnyerését évtizedekkel megelőzte. A kapcsolat abban rejlik, hogy a 19. század végétől USA-beli iskolákban alkalmazott kooperatív módszer, és a 20. század második felétől rohamléptekkel fejlődő infokommunikációs technológiák (IKT), egyaránt a hagyományos oktatás kiegészítő elemeiként, új alternatívaként kerültek be az iskolák mindennapjaiba.

Helyes bevezetésük nagyszerúen kiegészíti a tanórát. Az újdonság, érdekesség növeli a tanulók motivációját, fegyelmét. Használatuk közben a pedagógusok is kooperatívabbak, együttmüködőbbek lettek. Megtapasztalják az IKT nélkülözhetetlenné válását. Ennek hatására a legkülönfélébb iskolai termekben is lehetővé teszik a gyermekek számára a digitális eszközök használatát. A bátortalanabb pedagógusok számára is pozitív tény, hogy a digitális technológia gyors fejlődésével egyre kisebb mértékú a használatához szükséges technikai tudás. Nem utolsó szempont, hogy a korábbi nehéz tankönyveket kiválóan helyettesíti az apró adattároló eszközök valamelyike (Hunya, 2011).

\section{Tanító a 21. században}

A 21. századi IKT szorosan integrálódott a telekommunikációval, a multimédiás, és digitális eszközökkel; de nem maradhat ki ebböl a sorból a folyamatosan alakuló média világa sem. Ez a tény megkerülhetetlen. Különösen fontos lenne ezt tudatosítani a tanulási-magatartási nehézségekkel küzdő gyermekkel foglalkozó pedagógusoknál. Az IKT eszközök fejlesztő hatása nem megoldás minden problémára, amivel az oktatás szereplői szembesülnek. Ám igen jelentős, már kipróbált és eredményesnek bizonyult tapasztalat alapozza meg használatukat.

A tanítók többsége nyitott a technikai eszközök alkalmazására, ám eközben óvatos, fenntartással él. Utóbbinak nem a szük látókör az oka, hanem éppen az, amiért ezt a hivatást választották. A gyermekek szeretete, a közösség, az emberi kapcsolatok kialakítása, a tanulók értelmének fejlesztése, tudásuk szélesítése, elmélyítése. Az óvodai játékos, tevékenykedtető ismeretszerzés és a felsőbb iskolai évfolyamok ismeretcentrikus oktatása között igyekeznek átmenetet, ezen túl a további tanulmányokhoz, az életben várható feladatokhoz megfelelö alapokat biztosítani. Ebbe a struktúrába kell körültekintően bevonni az IKT eszközöket.

Egészen a digitális médiumok széleskörü elterjedéséig, később pedig az infókommunikációs ugrás bekövetkeztéig a szemléltető eszközökre, oktatástechnikai alkalmazásokra, a tudásközvetítési folyamat támogatójaként, kiegészítőjeként tekintettek. Gyökeresen megváltozott a helyzet az említett két technológiai „pillanat” bekövetkezése óta. Olyan mértékủ hatással szembesült a társadalom, amely meg- 
kérdőjelezte az addigi pedagógiai folyamatok jövőbeni alkalmazását, hatékonyságát. Ezek biztosítása nagyrészt a pedagóguson múlik. Mindez új megközelítést, attitüdöt kíván tőlük.

Ez nem más, mint a magánéletben hellyel-közzel, egyéntől függő módon és különböző szinten alkalmazott IKT használatot integrálják az iskolai oktatásba. Az otthoni tapasztalatok, az eszközhasználat iskolai környezetbe való adaptálásában jelentős szerepe lehet a tanítók életkori, nemi megoszlásának. Találhatunk olyan visszahúzódó, hagyományos elveket valló, régi, bevált eszközöket alkalmazó, több évtizede tanító pedagógust, akik az újdonságokat először gyakrabban elutasítják, és később is nehezen fogadják el, a módszertani, technikai haladással szemben is halogató taktikát folytatnak. Rajtuk kívül az elnőiesedő pálya, az intézmény falain kívül, a technikai eszközök többségének férfiak általi kezelése, szervizelése, a bevett gyakorlatot nehezebben váltó idősebb generáció, mind-mind sarokköve lehet a sikeres - és szükséges - változásnak.

Ellenben nem feledkezhetünk meg arról a tényről sem, hogy a pedagógusok naponta szembesülnek a hatékony munka érdekében - többnyire a gyermekekkel való interakció során megnyilvánuló - megoldásra váró helyezettel, kihívással. Ez nem feltétlenül kompenzálja a kezdeti ellenérzést, a felmerülő nehézségeket, de alapot képez a módszeres, esetenként hosszan tartó folyamathoz, amely a változáshoz vezet. Sőt kellő gyakorlatot, pozitív szemléletet, stratégiákat alakíthat ki a váltás eredményes végrehajtásához. A pedagógusok, a modern társadalom tagjaként otthonaikban, szabadidejükben természetesen találkoztak a számítógéppel, a hozzá kapcsolható IKT eszközök némelyikével. Ez ad némi alapot az iskolai alkalmazások bevezetéséhez. Ugyanakkor ez összehasonlíthatatlanul más helyzet, mint az iskolában elvárt pedagógusi szerep.

Bármennyire is merevnek tünik az iskolarendszer és annak nevelési stratégiája a jelentősen megváltozott a pedagógus szerephez képest, nem feledhetjük el fontosságát. Keretet, hátteret, szakmai mühelyt biztosít az iskolában oktatási szakemberek számára, a rájuk bízott diákokkal való tevékenységük során. Azzal, hogy nem a tanuló fölé magasodó, a tudást árasztó személy korunk pedagógusa, hanem az információs világban való eligazodást támogató, kompetenciákat fejlesztő, problémamegoldó gondolkodásra felkészítő mentor (Körösné, 2009) - még nem könynyebb, sőt egyes esetekben nehezebb a helyzete, mint korábban.

Az oktatásirányítás idejekorán felismerte az IKT jelentőségét (Földes és Körösné, 2006). Ennek jeleként az elmúlt két évtizedben széles körben megkezdődött a fejlesztés. A pedagógusok számára pályázatok útján elérhető informatikai eszközöket biztosítottak, eszközhasználattal, módszertani újdonságokkal kapcsolatos tanfolyamok tömegét szervezték. Ezeken elsősorban a téma iránt nyitott, érdeklődő kollégák vettek részt. Sokan éppen azért, mert rendelkeztek a magánéletükből vett előzetes ismeretekkel, de mélyebb tudás birtokába kívántak jutni. Elérendő cél továbbra is az informatikai, IKT ismeretek, eszközök megismertetése, tanításba való 
integrálása oly módon, hogy ne korlátozódjon az érdeklődőkre, hanem a ma még passzív többség is bevonásra kerüljön.

Oktatásunk eljutott a nem direkt módon történő informatika tanítás állapotába. A kifejlesztett eszközök nagymértékben támogatják az oktatókat az egyéb tanórák során alkalmazható digitális tartalmak használatában. Az utóbbi 2-3 évben a tankönyvkiadók is nagyot „léptek” ebbe az irányba. Akad olyan tankönyvcsalád, ahol a komplett tananyag, az összes kiadvány, azoknak minden oldala elérhető elektronikus formában (Hunya, 2011). Ez a virtuális bőség azonban vitathatatlan előnyei mellett negatív folyamatokat is generált. A nyitottabb, érdeklődőbb pedagógusok örömmel élnek a lehetőséggel, és igyekeznek megismerni, használni ezeket a munkájuk során. Sajnos nem egyedi eset, amikor túlzottan kötődnek ezekhez az eszközökhöz. Előfordul, hogy a testnevelést kivéve minden órán, folyamatosan találnak lehetőséget alkalmazásukra gondolván, hogy az eszköz használata korszerübbé teszi az oktatást, megkönnyíti a tanítást. Pedig a modern eszközök is valaminek a megtanitását segítik, amellyel a diákok tanórai munkája színesebbé, élménydúsabbá válhat.

Kiváló kontroll lehetőség - egyfajta tükör lehet -, amikor az IKT alkalmazásba belelelkesült pedagógus néhány hónap használatot követően áramszünet, vagy meghibásodás okán mellőzni kényszerül ezeket az eszközöket. Ekkor derül ki, hogy így is jól müködő, hatékony, a gyermekek számára érdekes, izgalmas tanóra következik-e, vagy netán rá kell döbbennie arra, hogy nehezen kezelhetö helyzetbe került, frusztráltnak és eszköztelennek érzi magát. Nem szabad megfeledkeznünk arról, hogy a tanulóknak szüksége van a közös alkotás örömének átélésére, amelyet kiegészít a tanári magyarázat. Ehhez hatékonyan kapcsolódhat egy kisfilm, kép, netán interaktív feladat, olvasás órán ugyanúgy, mint technika órán.

A továbbképzések irányába elvárásként fogalmazódott meg a gyakorlatorientált, tanórai tapasztalatokat adaptáló, valós tanítási szituációkat bemutató - lehetőleg a pedagógus saját közegében történő kipróbálást lehetővé tevő - jelleg. Ez tanítói magabiztosságot indukálna a tanítási folyamatok során, ami lényeges szempont a saját tudást bizonytalannak érző gondolatok mellett, ezen kívül támogat abban is, hogy egyensúly alakuljon ki az IKT alkalmazás terén is. Abban is segítséget nyújthat, hogy egy projektor vagy interaktív tábla valóban emelje a tanítási óra értékét ahelyett, hogy megragad egy - tankönyvnél nagyobb méretü - szemléltető eszköz szerepében.

A tanítók felkészülésük során gyakran támaszkodnak virtuális ismereteikre, többségük önállóan és igényesen el tud készíteni beszámolókat, feladatlapokat. Ám időhiányra hivatkozva ezeket gyakran mellőzik. Ez csak részben érthető, mert bár egy színvonalas 20 perces prezentáció létrehozása időben valóban annak többszöröse lehet, de nem szabad elfelejteni, hogy a felkészülés megtérül, ugyanis a kész anyagot később újra hasznosíthatja (Tóth, 2010). Talán ennél is lényegesebb elem a kialakuló magabiztosság, amely digitális technológia használata során az esetle- 
ges visszafogottság helyébe lép. A pedagógusok infó-kommunikációs technológiával szembeni fenntartása többnyire két forrásból ered. Egyrészről a megszokott, a biztos áll szemben az újjal, ismeretlennel; másrészt a diákok előtti megszégyenüléstől való félelem is igen jelentős visszatartó erő. Nem meglepő, hiszen, amellett, hogy a pedagógusképzés általában nem készíti fel a leendő pedagógusokat az IKT alkalmazására, nem feledhetjük, hogy éppen zajlik a tanár-diák viszony jelentős átalakulása. Ez a tekintély átértelmezését, a tudásforrás fensőbbségének partneri viszonnyá való módosulását is jelenti. Ez a feszültség könnyen kezelhető, ha a pedagógus nem a technika használatára, hanem az átadott tartalomra helyezi a hangsúlyt (Jakab, 2011). Legmegfelelőbb időszak ennek bevezetésére, az iskola kezdő szakasza, ahol jelentős az informális tanulás és az interperszonális kapcsolatok szerepe (Tóth, 2010). Ezen túl pedig még nem jellemző a kisdiákokra az IKT eszközök mélyreható ismerete. Nyugodtabb tempóban, a tanuló és pedagógus együtt, az ismereteket megosztva juthat tovább. A gyermekek értékelik, ha partnerként tekintünk rájuk. Amikor az interaktív táblát, számítógépet és egyéb digitális eszközöket a gyermekekkel együtt használva, a tanító esetenként megmarad a mentor szerepénél, a diákok. már alsó tagozatban megbízhatóan, büszkén elvégeznek előkészítő, szervezési feladatokat. Örömmel bekapcsolják a számítógépet, szünetekben zenét keresnek, hallgatnak, esetleg mesefilmet is nézhetnek. Új lehetőség, ha tabletek, kamerák, mobiltelefonok, sőt a facebook is felkerül az oktatási palettára, újszerü alkalmazási módokkal beépülve a mindennapi tanítási gyakorlatba (Kósa, 2007). Ehhez társul a számítógépes eszközök azonnali visszacsatolást lehetővé tévő tulajdonsága, emellett az észlelés komplex jellege segíti a feldolgozási folyamatot, a megértést (Földes és Körösné, 2006). Ezzel a pedagógus munkája is könnyebbé, hatékonyabbá, a tanórák hangulata kellemesebbé válik, egyúttal kiváló motiváló erő diáknak, pedagógusnak egyaránt.

Meglepö módon a fiatalabb generáció tagjai között is találunk a számítógéppel szemben elutasító hozzáállást. Ez alapján nem véletlen, hogy akad pedagógus, akinek otthonában nincs számítógép, internet; és nem használja azokat sem az iskolában, sem más helyen. Felvetődik a kérdés, hogy miért? Hol van itt megújulás? A pedagógusnak újra és újra szükséges megújulnia ahhoz, hogy az egymást követő korosztályokat feltöltődve, friss lendülettel kalauzolja végig az iskolás éveken. Fehér Péter 1999-ből való meghatározása - amelynek minden betűjével egyetértek nagyszerủen elénk vetíti, hogy számára milyen a modern tanár: ,egy olyan új szellemü vezető, aki képes hozzásegíteni a tanulókat az aktív, önálló, de mégis közös ismeretszerzéshez, és folyamatos önképzéssel lépés tart az újdonságokkal, netán a saját tanulóival..." (Fehér, 1999, 185. o.). Mint látható, a pedagógus szerepe - a tanárok félelmeivel ellentétben - nem csökken, hanem erösödik (Koltay, 2010), csak éppen más formában nyilvánul meg (Forgó, 2009).

A harmadik évezredben a pedagógusok munkája során elengedhetetlen a korszerü IKT eszközök, az internet használata. Ennek feltétele az intézmények megfe- 
lelő színvonalú és mennyiségű, szoftver- és hardvereszköz ellátottsága (Körösné, 2004). Nélküle esélye sincs az ezeket az eszközöket hatékonyan, szakszerủen alkalmazni tudó és akaró tanítónak a hátrányok kompenzálására, a felzárkóztatásra. A 21. században nem az a kérdés, hogy használjuk-e az IKT eszközöket az oktatásban, sokkal inkább, az hogy képesek vagyunk-e itt is tudatosan, és változatosan alkalmazni, ahogy a hétköznapi életünkben már természetessé vált.

\section{Összegzés}

Tudásalapú társadalmunkban elengedhetetlenné vált a digitális írásbeliség (Körösné, 2004; Koltay, 2010), és ezzel párhuzamosan a kritikus gondolkodás. Ma, mindennapi életünknek szinte nincs olyan területe, ahol a médiumok virtuális világának tárgyiasult formái - az IKT eszközök - ne jelentek volna meg, miközben gyors térnyerésükkel háttérbe szorították a hagyományos eszközöket. Az utóbbi évtizedben, az oktatási folyamatokban is megfigyelhető, hogy az informatika, az infó-kommunikációs technológiák alkalmazása egyre nagyobb hangsúlyt és szerepet kap. Az oktatás is elindult a tevékenységorientált és a konstruktivista tanulási modell felé (Komenczi, 2009), amely egyik jellemzője az önálló tudásszervezésre alkalmas eszközök használata. Az iskola mindennapi gyakorlatába fokozatosan beépülnek a multimédiás szoftverek, a futtatásukra alkalmas eszközök: számítógép, projektor, interaktív tábla, szkenner, vagy éppen egy másik, otthon már használt digitális eszköz.

Ám nem elegendő - lásd a korábbi nagy fejlesztési hullámokat - dömpingszerüen rázúdítani az oktatásra a technikai eszközöket. A sikeres adaptálás, hatékony alkalmazás lényeges eleme a rendszerszemlélet (Tóth, 2010). Szükséges a pedagógusok attitüdjeinek módosítása, az eszközök ismerete, ezen túl pedig a megfelelö motiválás is. Csak pozitív hozzáállású és kellően képzett pedagógusokkal sikerülhet az iskolákban eredményesen és hatékonyan használni a rendelkezésre álló technikai eszközöket.

Sajnos nem mindenki nyitott az információ- és kommunikációs eszközök használatára (Körösné, 2009), és akadnak olyan pedagógusok is, akik az „,ismeretlentől" való félelmük miatt nem használják a számítástechnikai eszközöket. Ahhoz, hogy teljesüljön az alsó tagozat feladata - miszerint gyermekek természetes kíváncsiságára, nyitottságára alapozva kialakuljon a tanuláshoz való pozitív attitüd, illetve az élethosszig tartó tanuláshoz fontos kulcskompetenciák, és felkészüljenek arra, hogy sikeres felnőttként éljenek az információs korban - a pedagógusok nem kerülhetik meg az IKT eszközök ésszerủ arányban és megfelelő módon történő alkalmazását.

A szükséges technikai háttér mellett elengedhetetlen a jó gyakorlatok továbbadása (Körösné, 2004). Erre nagyszerü alkalom lehet egy bemutató óra, ami a továbbképzéseken kívül a tanító/tanárképzésben is megalapozhatná a hozzáértő, ma- 
gabiztos pedagógust. Hiszem, hogy a legtöbb pedagógus tudja, és elfogadja, hogy az IKT eszközökkel támogatott oktatásé a jövő.

A szülők jelentős része is elfogadja azokat a - tudományosan is megalapozott gyakorlati tapasztalaton nyugvó megnyilatkozásokat, amik az IKT eszközök oktatásba való nagyobb mértékü bevonását szorgalmazzák. Alkalmat jelent ez arra, hogy jobban megértsék gyermekeik - a digitális bennszülöttek (Prensky, 2001) viselkedésbeli, tanulási és figyelmi másságát az általuk korábban természetesnek vélttől. Bár a diákok, IKT környezetben felnőve, könnyen és gyorsan megtanulják az ahhoz tartozó ismereteket, a megfelelő tapasztalat nélkül nem ismerik fel az IKT eszközök, az internet használatának veszélyeit.

Az IKT nem egyszerüen új technológia. Olyan tényező, amely kényszerítő erővel hat a korábbi pedagógiai paradigmára, a tudásról, a jövőről alkotott képünkre, mindennapi életünkre. Azonban hiba volna a színvonalas oktatás érdekében kötelezővé tenni a digitális és IKT eszközöket (Tarné Éder, 2013). Jó példa erre a hálózati tanuláson alapuló konnektivista tanuláselmélet (Jakab, 2011), amely információs világunk legfrissebb neveléselméleti „gyermeke”. Bármennyire is az új nemzedékre szabott forma, elsősorban nem az iskola kezdő szakaszában alkalmazható. Eközben alsó tagozaton is elindult, ha akadozva, a szükségesnél lassabban is, azon pedagógusok körében a szemléletváltás, akik tapasztalták az IKT használat elönyeit.

Állítom, hogy a szakemberek (pedagógusok, tudósok, kutatók), és a szülök egyaránt támogatják, sőt egyre inkább elvárják az IKT eszközök alsó tagozatban való használatát. Nem meglepő, hiszen a folyamat, amelyben az emberek, a társadalom - az idő előrehaladtával, egyre nagyobb mértékben - hozzáidomul az adott technika minél kényelmesebb, minél nagyobb mértékü használatához jelenleg is tart. Véleményem szerint nem zárkózhat el egyetlen oktatási intézmény sem ezektől a folyamatoktól, főképp azért, hogy biztosítson más szemszögböl való rálátást is a gyermekek számára, mert alkalmazni kell a technikát, nem a technika által irányítottan élni.

\section{Irodalom}

Békési Attila (2010): Az IKT eszközök az oktatásban. Szakdolgozat, Debreceni Egyetem MII. URL: http://ganymedes.lib.unideb.hu:8080/dea/bitstream/2437/105068/1/Szakdolgozat_Bekesi_Attila_titkositott.pdf Letöltés ideje: 2014. július 16.

Bessenyei István (2009): Képernyö, tanulási környezet, olvasás - Seymour Papert tanuláselméleti nézetei az olvasás kapcsán. URL: http://www.ofi.hu/tudastar/kepernyo-tanulasi Letöltés ideje: 2013. november 19.

Csepeli György (2003): A digitális generáció. URL: http://www.csepeli.hu/pub/2003/csepeli_ et_2003_45.pdf Letöltés ideje: 2013. december 8.

Csík Tibor (2011): A digitális bennszülöttek és az olvasás. Új Pedagógiai Szemle, 10. sz. 30-47. URL: http://www.ofi.hu/tudastar/upsz-2011-10 Letöltés ideje: 2013. november 5. 
Fehér Péter (1999): A számítógép az oktatásban a harmadik évezred küszöbén. Új Pedagógiai Szemle, 7. sz. 181-189. URL: http://epa.oszk.hu/00000/00035/00029/1999-07in-Feher-Szamitogep.html Letöltés ideje: 2013. december 10.

Földes Petra és Körösné Mikis Márta (2006): Jó gyakorlatok az alsó tagozatos informatikában. Új Pedagógiai Szemle, 4. sz. 101-114. URL: http://www.ofi.hu/tudastar/jogyakorlatok-also Letöltés ideje: 2013. november 10.

Forgó Sándor (2009): Az új média és az elektronikus tanulás. Új Pedagógiai Szemle, 8-9. sz. 91-96. URL: http://epa.oszk.hu/00000/00035/00135/pdf/EPA00035_upsz_20090809_091-096.pdf Letöltés ideje: 2013. december 31.

Harangi László (2011): Gyermekek és fiatalok motiválása, az egész életen át tartó tanulásra. Új Pedagógiai Szemle, 11/12. sz. 23-29. URL: http://www.ofi.hu/tudastar/upsz-beliv2011-11-12 Letöltés ideje: 2013. december 21.

Hunya Márta (2011, szerk.): Iskolaportrék - Iskolák az IKT használat tükrében. OFI, Budapest.

Jakab György (2011): Írás és olvasás a digitális kultúrában. Új Pedagógiai Szemle, 10. sz. 92-98. URL: http://www.ofi.hu/tudastar/upsz-2011-10 Letöltés ideje: 2013. november 21.

Kikindai Kristóf (1990): A laterna magicától a videotechnikáig. - In: Hargitai József szerk.: Pedagógiai írások. Vas megyei Pedagógiai Intézet, Szombathely, 165-174.

Koltay Tibor (2010): Az új média és az írástudás új formái. Magyar Pedagógia, 4. sz. 301-309.

Komenczi Bertalan (2009): Elektronikus tanulási környezetek. Gondolat Kiadó, Budapest

Komenczi Bertalan (2009): Az információs társadalom iskolájának jellemzői. OFI URL: http://www.ofi.hu/tudastar/informatika-oktatasban/informacios-tarsadalom Letöltés ideje: 2013. december 11.

Kósa Éva (2007): A média szerepe a gyerekek fejlödésében. Utolsó letöltés: 2013. november 19. http://www.mediatudor.hu/download/tudastar_szakirodalom_kosa.doc

Körösné Mikis Márta (2003, szerk.): Informatika gyermekkorban - Hazai helyzetkép. In: Iskola - Informatika - Innováció. Országos Közoktatási Intézet, 89-99. Utolsó letöltés: 2014. július 16. http://www.ofi.hu/tudastar/iskola-informatika/korosne-mikis-marta

Körösné Mikis Márta (2004): IKT az oktatás kezdő szakaszában. OKI PTK Utolsó letöltés: 2013. november 25. http://www.ofi.hu/tudastar/gyermekinformatika/ikt-oktatas-kezdo

Körösné Mikis Márta (2007): A pedagógusok felelőssége és lehetőségei a gyermekek informatikai nevelésében. In: A kiskorúak védelme a médiaszolgáltatásokban. 49-51. Alkalmazott Kommunikációtudományi Intézet, Budapest

Körösné Mikis Márta (2009): Az informatika tantárgy helyzete a kérdöives felmérés alapján. URL: http://www.ofi.hu/tudastar/tanitas-tanulas/informatika-tantargy Letöltés ideje: 2013 . december 8 .

Körösné Mikis Márta (2009): Tanulás a 21. században. OFI URL: http://www.ofi.hu/ tudastar/korosne-mikis-marta/tanulas-21-szazadban Letöltés ideje: 2013. december 1.

Lengyelné Molnár Tünde (2013): Az információs és kommunikációs technológiák, mint tanulástámogató rendszer. In: Médiatudatosság az oktatásban OFI konferencia, ppt. Budapest. URL:http://www.ofi.hu/hirek-aktualitasok/lengyelne-dr-molnar Letöltés ideje: 2014. július 15 . 
McLuhan, M. (1969): The Playboy Interview. Playboy Magazine, March. URL: http://www. nextnature.net/2009/12/the-playboy-interview-marshall-mcluhan/ Letöltés ideje: 2013. december 14 .

Prensky, M. (2001): Digital, natives, digital immigrants. On the horizons(MCB Univ. Press. Vol. 9. No. 5. http://www.marcprensky.com/writing/Prensky\%20-\%20Digital\%20Natives, \%20Digital\%20Immigrants\%20-\%20Part1.pdf Leöltés ideje: 2015. augusztus 8.

Szakadát István (1992): Az elektronizáció folyamatának terjedése a nyolcvanas években, In: Farkas János - Szakadát István (szerk.): Csúcstechnológiák és döntési csúcsok. MTA Politikai Tudományok Intézete. 8-58. URL: https://www.academia.edu/1614260/Az elektronizacio_folyamatanak_terjedese_a_nyolcvanas_evekben_Magyarorszagon Letöltés ideje: 2014. július 17.

Szimedli József (2006): Oktatástechnológia. URL: http://www.bdf.hu/oldinformatika/szjozsef/ Dokumentumok/Oktat\%C3\%A1stechnol\%C3\%B3gia.doc Letöltés ideje: 2013. december 26 .

Tarné Éder Marianna (2013): Digitális osztályterem - jó gyakorlatok az alapozó szakaszban IKT eszközökkel. 2. Digitális pedagógus konferencia. URL: http://www.osztalyfonok. hu/cikk.php?id=1240 Letöltés ideje: 2013. december 2.

Tóth Teréz (2010, szerk.): Kerekasztal beszélgetés az IKT technológia paradigmaváltó hatásairól az egész életen át tartó tanulás kontextusában. Új Pedagógiai Szemle, 1-2 sz. 162-180. URL: http://epa.oszk.hu/00000/00035/00139/pdf/EPA00035_upsz_2010_1-2_ 162-180.pdf Letöltés ideje: 2013. december 27. 